\title{
Natural hybridization and potential seed set of sympatric Populus nigra and Populus $\times$ canadensis along the river IJzer in Flanders (Belgium)
}

\author{
An Vanden-Broeck ${ }^{1, *}$, Karen Cox $^{1}$ \& Marc Villar $^{2}$
}

${ }^{1}$ Instituut voor natuur- en bosonderzoek, Gaverstraat 4, BE-9500 Geraardsbergen, Belgium

${ }^{2}$ INRA - Centre d'Orleans Unite Amélioration, Génétique et Physiologie Forestières, 2163 Avenue de la Pomme de Pin, CS 40001 Ardon, FR-45075 Orléans Cedex 2, France

*Author for correspondence: An.vandenbroeck@inbo.be

\begin{abstract}
Background and aims - In Europe, native Populus nigra generally grows sympatric with related exotic cultivated poplars. Hybridization followed by introgression and genetic swamping is often mentioned as a potential threat for the conservation of P. nigra. This potential threat is supposed to be higher when the cultivated poplars are reproductively more effective compared to $P$. nigra. We investigated hybridization events of $P$. nigra females with cultivated $P . \times$ canadensis and $P$. nigra 'Italica' along the IJzer river in Flanders (Belgium). We also compared the reproductive potential of $P$. nigra and $P . \times$ canadensis.

Methods - After first determining the genotypic diversity within $P$. nigra, we looked for diagnostic microsatellite alleles of $P$. deltoides in the offspring of open-pollinated $P$. nigra. We also studied the possible paternity by the cultivar $P$. nigra 'Italica'. The reproductive potential of $P$. $\times$ canadensis and $P$. nigra was compared in terms of potential seed set.

Key results - This study provides evidence for natural hybridization between $P$. nigra and $P$. $\times$ canadensis in West Flanders. In $58 \%$ of the seedlings from the open pollinated P. nigra trees, at least one diagnostic allele of $P$. deltoides was detected. P. nigra 'Italica' was likely the father of only one seedling. The exotic $P$. $\times$ canadensis showed a significantly higher potential for seed set compared to native $P$. nigra. The genotypic diversity of $P$. nigra was extremely low with only two (female) genets among 209 black poplars. Conclusions - Natural hybridization with $P$. $\times$ canadensis occurs and may pose a significant threat to the conservation of $P$. nigra in West Flanders. To reduce the risk of introgression and genetic swamping of $P$. nigra by $P$. $\times$ canadensis, we strongly advise reforestation using multiple genotypes of $P$. nigra from neighbouring regions taking into account balanced sex-ratios.
\end{abstract}

Key words - Populus nigra, Populus $\times$ canadensis, hybridization, introgression, genetic diversity, potential seed set, reproductive potential.

\section{INTRODUCTION}

Natural hybridization of a rare species with a more common taxon may result in the extinction of the former (Ellstrand 2003). Populus nigra L., the European black poplar, is considered a locally endangered native tree species in Europe. Hybridization along with introgression and genetic swamping by commonly planted exotic poplars is assumed to threaten the genetic integrity of P. nigra (e.g. Lefèvre et al. 2001, Heinze 2008, Smulders et al. 2008a).

In Belgium, autochthonous $P$. nigra is only represented by individual relict trees occurring mainly in the valley of the river IJzer (West Flanders), the focus area of this study. Here, cultivated trees of Populus $\times$ canadensis Moench $(P . \times$ euramericana (Dode) Guinier cv., synon.) frequently occur sympatrically with autochthonous $P$. nigra.

Trees of $P . \times$ canadensis are frequently planted for wood production. They are generally first-generation $\left(\mathrm{F}_{1}\right)$ hybrids resulting from a cross between a female tree of the North American P. deltoides Bartr. ex Marsh. and a male tree of the Eurasian $P$. nigra. Also, second-generation hybrids resulting from a backcross of a $\mathrm{F}_{1}$-hybrid to $P$. nigra are sometimes planted in commercial plantations. $P$. $\times$ canadensis generally appears in monoclonal plantations (Pinon 1992). Only 26 genets of $P$. $\times$ canadensis are listed in the Belgian List of Approved Basic Material for the Production of Forest Reproductive Material. From this list, only a few genets are frequently planted and many of them are highly related (fullsibs). For example, in Flanders and during the period 2005 
2007, afforestation with $P$. $\times$ canadensis supported by grants comprised only 13 different genets (Peter Simon, Flemish Government Department for Agriculture and Fisheries, personal communication). This resulted in very low genetic diversity within and among plantations of $P . \times$ canadensis.

The potential hazard from natural hybridization with cultivated poplars is the loss of P. nigra as a pure species. The loss of $P$. nigra may result from genetic assimilation by the more numerous cultivated poplars or from outbreeding depression. Outbreeding depression is the loss of specific, coadapted gene complexes and occurs when hybrid offspring has lower fitness than offspring from intraspecific mating events. In particular, the potential hazard of interspecific hybridization is higher when $P . \times$ canadensis is more numerous and reproductively more effective by producing more pollen and / or seed compared to P. nigra (Ellstrand 2003). Although commercial hybrid poplar clones are assumed to be reproductively less effective than their related wild poplar species (Stettler et al. 1996, Strauss et al. 2001), information about the reproductive capacity of hybrid poplar plantations is scarce. Despite studied for many plant species (Burd et al. 2009), no report exists on the number of ovules per flower or on the potential for seed set of Populus species, to our knowledge.

In addition, natural hybridization with the cultivated clone P. nigra 'Italica', known as the Lombardy poplar, may also pose a threat to autochthonous $P$. nigra resources. $P$. nigra 'Italica' is the most ancient poplar cultivar and the one with the widest distribution (Chenault et al. 2011). This male clone is frequently planted as a windbreak in rural and urban landscapes across the temperate zone and is supposed to be a major pollen producer (Chenault et al. 2011). Massive pollen flow from $P$. nigra 'Italica' may result in the loss of genetic diversity of the autochthonous $P$. nigra populations which can lead to their eventual extinction. Since the cultivar is part of the P. nigra species, barriers against introgression into autochthonous wild $P$. nigra populations could be assumed to be low (Chenault et al. 2011).

Vanden Broeck et al. (2004) presented evidence for natural hybridization between Populus nigra and $P . \times$ canadensis. They hypothesized that natural backcross events of $P$. nigra females with pollen of $P . \times$ canadensis are rare and seem to occur only occasionally in solitary $P$. nigra females when male hybrids are locally abundant. Nevertheless, this evidence for natural hybridization between $P$. nigra females and $P . \times$ canadensis males was based only on one case-study and one single tree-progeny. Furthermore, the results of the latter study contrast with results from other studies where no natural hybridization was detected in the offspring of open pollinated $P$. nigra, although males of $P$. $\times$ canadensis were present in the vicinity (Benetka et al. 1999, Fossati et al. 2003, Tabbener \& Cottrell 2003, Heinze 2008). Former

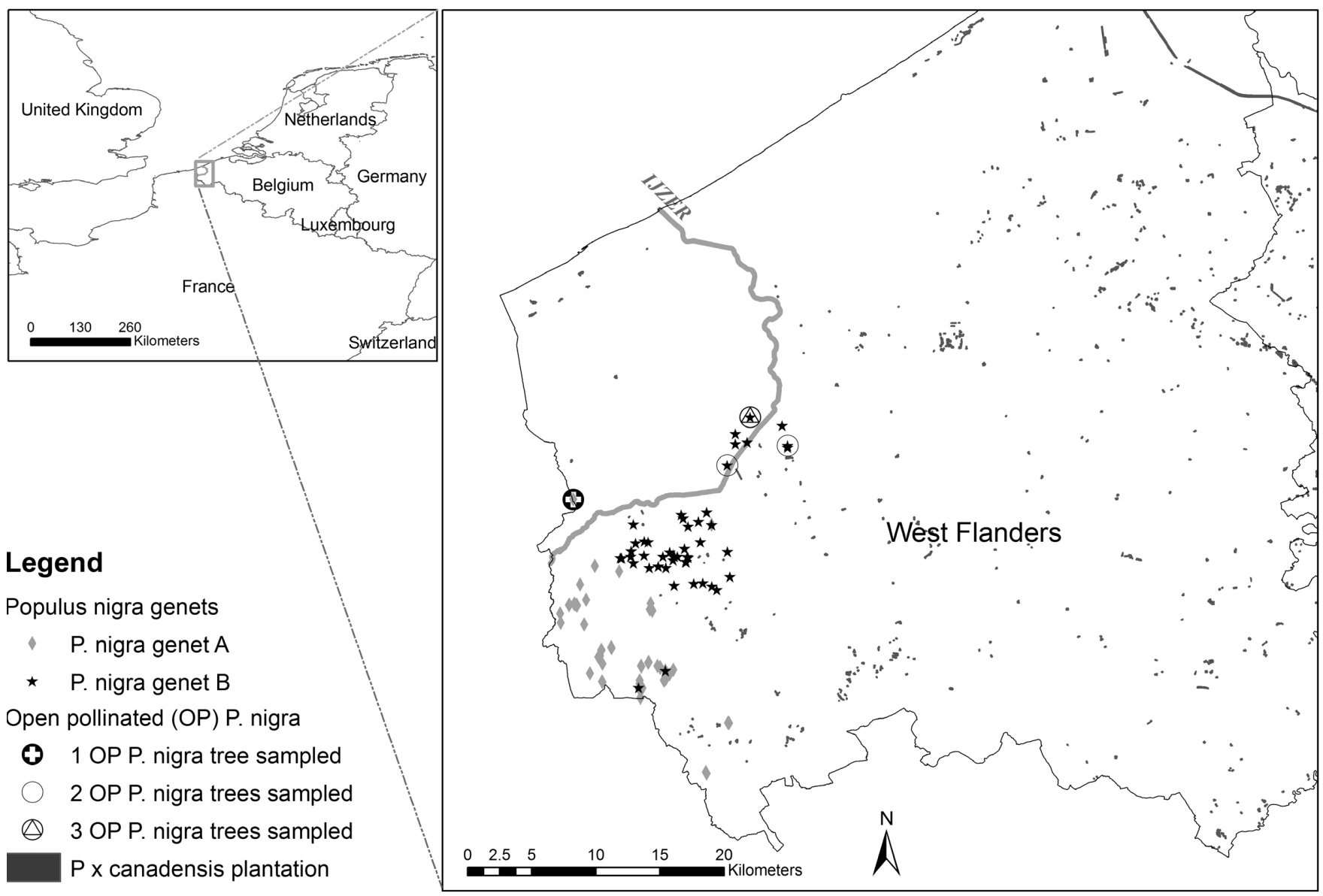

Figure 1 - Location of the sampled Populus nigra trees in the province West Flanders, Belgium. Seeds were harvested on eight openpollinated black poplar trees located in the valley of the river IJzer. 
Table 1 - Number of seedlings per progeny from open-pollinated Populus nigra carrying diagnostic microsatellite alleles of $P$. deltoides at loci Wpms09, Wpmgc14 and Wpms18.

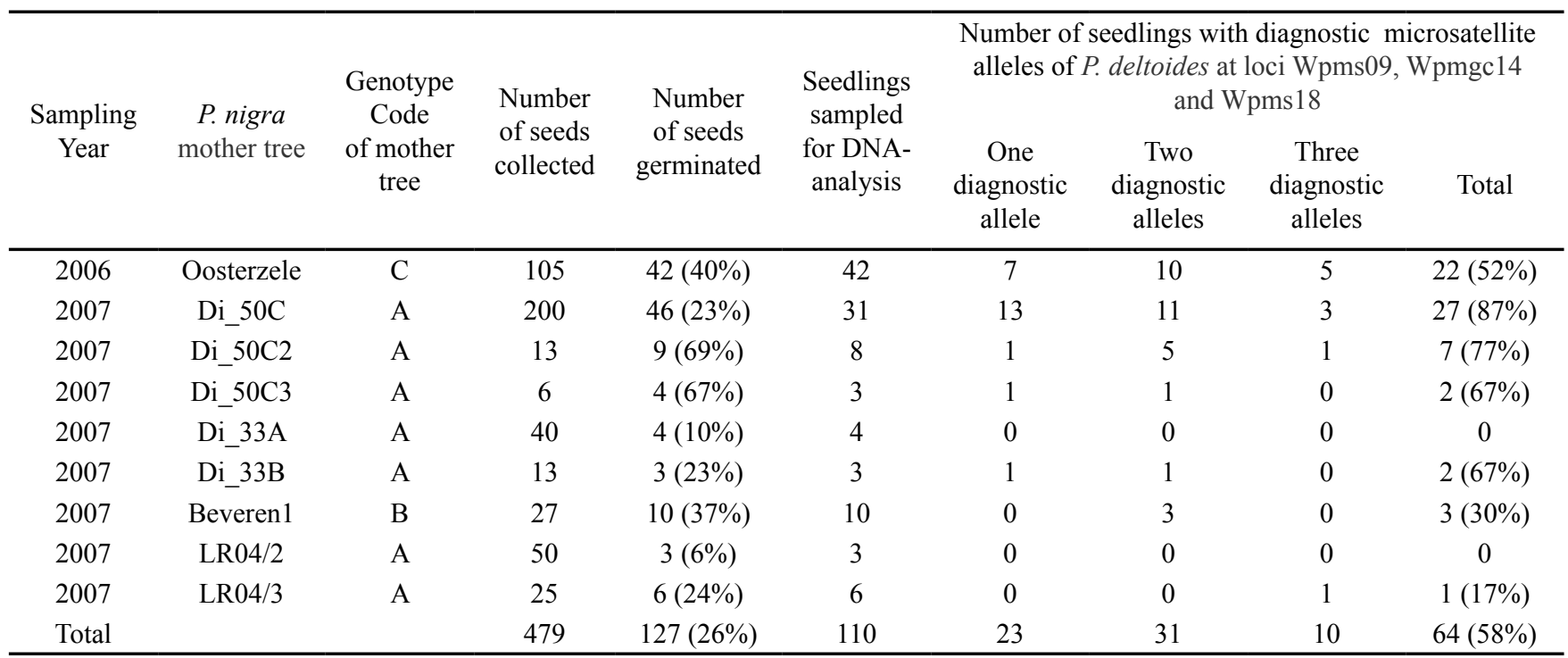

studies indicate the local demographic context and pre-mating reproductive barriers as important factors determining hybridization frequencies (e.g. Vanden Broeck et al. 2004, 2006, Ziegenhagen et al. 2008, Field et al. 2011). However, as evidence for natural hybridization between P. nigra and $P . \times$ canadensis is scarce, the significance of hybridization in the context of the conservation of $P$. nigra is controversial (Ziegenhagen et al. 2008, Csencsics et al. 2009).

The goal of this study is to provide more insight into the significance of hybridization to the conservation of $P$. nigra along the river IJzer. More specifically, we determine whether native $P$. nigra females hybridize with cultivated $P$. $\times$ canadensis and $P$. nigra 'Italica'. Also, we investigate the demographic and genotypic context of $P$. nigra in West Flanders. Finally, we compare the reproductive capacity in terms of the potential for seed set of the cultivated $P . \times$ canadensis with the native P. nigra. Based on the results we formulate practical guidelines for the restoration of black poplar along the IJzer in West Flanders.

\section{MATERIAL AND METHODS}

\section{Study area and plant material}

Putative autochthonous black poplar trees in the valley of the IJzer were selected from an earlier full inventory of autochthonous trees and shrubs in Flanders (Vander Mijnsbrugge et al. 2005). These trees were identified based on their morphological characters. The river IJzer is located in the province West Flanders, the westernmost province of Flanders (northern Belgium) that borders the North Sea and France. This river valley is characterized by a flat and open agricultural landscape. In spring 2007, we visited all 135 known locations with putative black poplars in the valley of the IJzer River. Young leaves were collected for DNA-extraction from generally one but up to 11 putative black poplar trees per location, because we expected a high level of clonality per location (Storme et al. 2004). This resulted in a total of 235 mature putative black poplar trees sampled to determine the genotypic diversity. When branches with flower buds were available, the sex of the tree was recorded. The locations of the sampled trees are given in fig. 1 .

To assess hybridization between female trees of $P$. nigra and male trees of $P$. $\times$ canadensis, we harvested seeds (halfsibs) on eight open-pollinated black poplar trees located in the valley of the river IJzer (fig. 1). Furthermore, we harvested seed on one tree located in Oosterzele in the valley of river Scheldt in the province East Flanders. These mother trees were surrounded by adult commercial plantations of the hybrid $P . \times$ canadensis within a distance of $100 \mathrm{~m}$. Seeds were sown in trays in the greenhouse within $24 \mathrm{~h}$ of collection. One month after sowing, seed germination percentages were recorded and leaf samples were collected from a total of 110 seedlings for DNA-extraction. The number of seeds genotyped per mother tree is listed in table 1. Young leaves were also sampled for DNA-extraction from the cultivated $P$. nigra 'Italica'.

To investigate the potential for seed set of $P$. nigra compared to $P . \times$ canadensis, branches bearing pistillate inflorescences were collected before or shortly after bud burst in April 2010 from eight and nine female trees of $P$. $\times$ canadensis and P. nigra, respectively. They were selected from the poplar collection of the Research Institute for Nature and Forestry (INBO, Geraardsbergen, Belgium) based on the presence of flower buds. The trees of $P$. $\times$ canadensis originated from seeds obtained from controlled crosses and therefore represented different genets. The female trees of $P$. nigra represented different genets from the valleys of the rivers Dender, Meuse and Scheldt which were genotyped previously by Storme et al. (2004). The origin of the plant material used for studying the seed production potential is presented in table 2. At the time of collection, the inflorescences extended about 0.5 to $1 \mathrm{~cm}$ beyond the bud scales and thus were not yet fully expanded and unpollinated. 
Table 2 - Characteristics of the Populus $\times$ canadensis and the Populus nigra trees analysed for seed set potential. NA: not assessed due to dropped catkins.

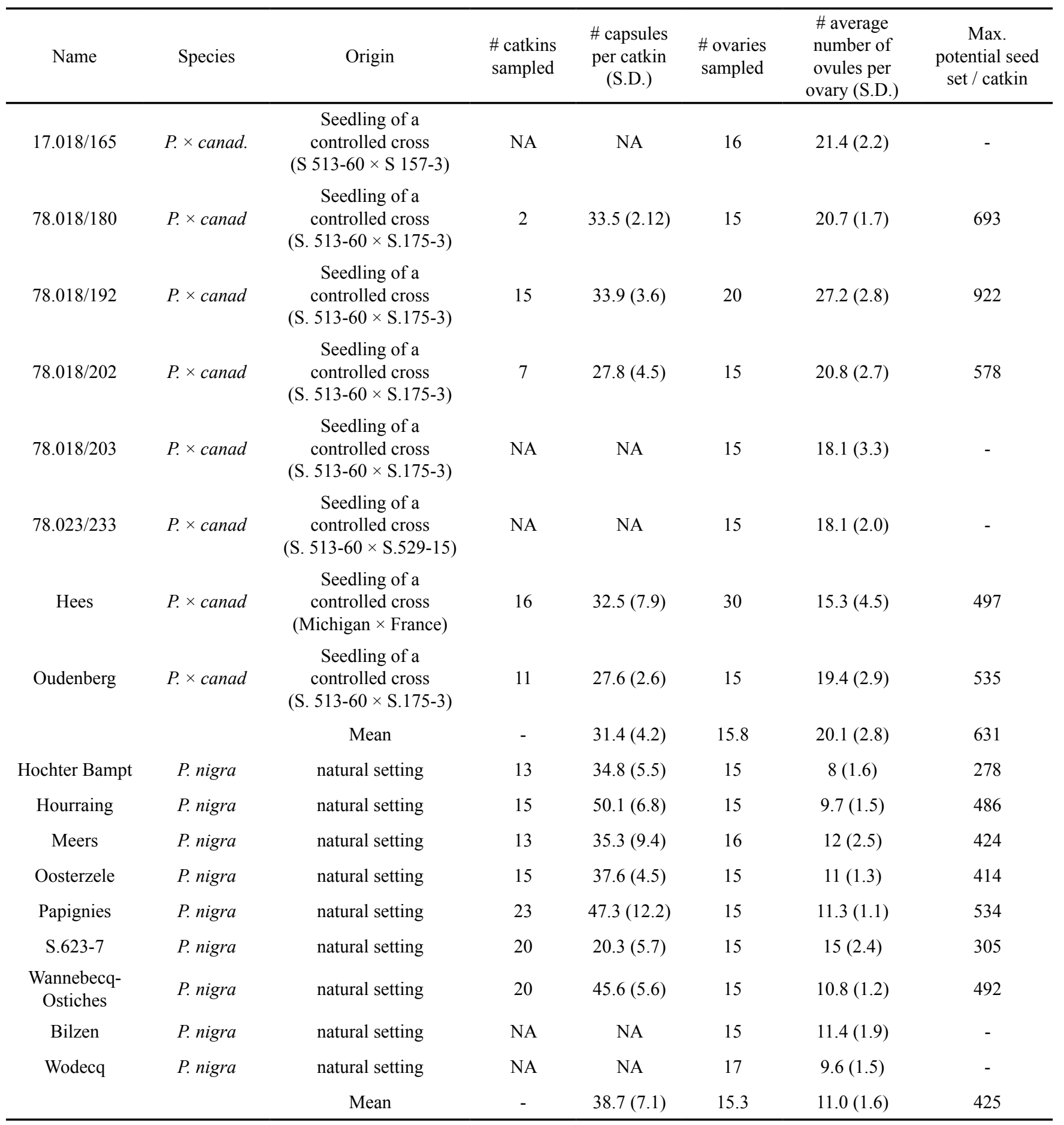

\section{DNA-extraction and microsatellite genotyping}

Young leaves were lyophilized prior to DNA-extraction. DNA was extracted using the Dneasy Plant Miniprep Kit (Qiagen, Helden, Germany). For the study of the genotypic diversity of $P$. nigra in the valley of the IJzer river, we analysed seven nuclear microsatellite loci: Pmgc14, Wpms05, Wpms09, Wpms14, Wpms16, Wpms19, Wpms22 (Smulders et al. 2001, van der Schoot et al. 2000). For the analyses of the half-sib progenies collected in the field from the open pollinated $P$. nigra mother trees, we analysed four nuclear microsatellite loci: Pmgc14, Wpms09, Wpms18 and Wpms20. These loci have proven to be diagnostic for differentiating $\mathrm{F}_{1}$ hybrids of $P$. $\times$ canadensis from non-hybrid $P$. nigra (e.g. Fossati et al. 2003, Vanden Broeck et al. 2004, Pospíšková \& Šálková 2006). They display species-specific alleles or alleles with a significantly different frequency between $P$. nigra 
Table 3 - Species-specific alleles (Pmgc14, Wpms09, Wpms18) or alleles with a significantly different frequency between $P$. nigra and P. deltoides (Wpms20) as found by Fossati et al. (2003).

\begin{tabular}{ccccc}
\hline Locus & $\begin{array}{c}\text { Allele } \\
(\mathrm{bp})\end{array}$ & P. nigra & $\begin{array}{c}\text { Allele frequency } \\
\text { deltoides }\end{array}$ & $\begin{array}{c}P . \times \\
\text { canadensis }\end{array}$ \\
\hline Pmgc14 & 199 & 0 & 0.600 & 0.158 \\
& 193 & 0 & 0.400 & 0.408 \\
Wpms09 & 234 & 0 & 1.00 & 0.583 \\
Wpms18 & 220 & 0 & 1.00 & 0.566 \\
Wpms20 & 224 & 0.154 & 0.800 & 0.625 \\
& 218 & 0 & 0.200 & 0.045 \\
\hline
\end{tabular}

and $P$. deltoides (table 3). Locus Pmgc14 was selected from the IPGC (International Populus Genome Consortium) SSR database (http://poplar2.cfr.washington.edu/pmgc). Wpms09 was described by van der Schoot et al. (2000), the other loci were selected from the study of Smulders et al. (2001). PCR reactions were performed as described by van der Schoot et al. (2000) and Smulders et al. (2001). The markers Pmgc14, Wpms05, Wpms09, Wpms16 were mapped by Cervera et al. (2001) and are completely unlinked. PCR reactions were run on a Spectrumedix SCE9610 fluorescent capillary sequencer and analyzed using the BaseSpectrum (Version 2.0) (Spectrumedix LLC, State. College, PA, USA).

In microsatellite genotyping, the observed size of a specific allele is generally an estimation of the absolute fragment size and may slightly vary between different studies. To enable the comparison of allele fragment sizes reported in former studies, we included the following control samples; five clones of $P$. deltoides (Harvard, S 9-2, S.4-89, S. 620-588 and S. 197B) and nine clones of $P . \times$ canadensis (Primo, Ghoy, Gaver, Gibecq, Ogy, Isières, Muur, Oudenberg, Vesten). Based on these control samples, we screened the genotypes of the half-sibs for alleles previously identified as diagnostic for $P$. deltoides by Fossati et al. (2003) (table 3 ). The widely planted male cultivar $P$. nigra 'Italica' was included to assess its role as a potential father for the openpollinated progenies.

\section{Assessment of the genotypic diversity of $\boldsymbol{P}$. nigra}

To detect if putative trees of $P$. nigra sampled in the field were in fact hybrids, we first screened the accessions for diagnostic alleles of $P$. deltoides at the loci Pmgc14 and Wpms09 (see also Fossati et al. 2003). Accessions showing a diagnostic allele of $P$. deltoides at one of these loci were considered hybrids and were eliminated from further analysis. Secondly, we defined the apparent number of different genets with the programme GENALEX 6.4 (Peakall \& Smouse 2006) based on the multilocus microsatellite genotypes of the trees sampled. Samples were identified as replicates from the same genet when they shared identical multilocus genotypes for six nuclear microsatellites (Wpms22 was excluded because of scoring difficulties, see below).

\section{Assessment of hybridization events with cultivated pop- lars}

Hybridization events of $P$. nigra females with $P . \times$ canadensis males were assessed based on the multilocus genotype of the half-sibs from the open-pollinated P. nigra trees. The maternal allele at each locus was subtracted from the genotype of each sampled seedling. This process of maternal exclusion revealed the multilocus haplotype of the paternal contribution. When at least one diagnostic allele of $P$. deltoides was found in the paternal haplotype of the multilocus genotype of the seedling, the seedling was considered to have a clone of $P$. $\times$ canadensis as father. The genotype of $P$. nigra 'Italica' was considered the likely father of a seedling if its multilocus genotype matched the paternal haplotype of the seedling for the four microsatellite loci.

\section{Assessment of seed set potential}

The branches bearing pistillate inflorescences were placed in tap water in glass jars in the greenhouse (about $20^{\circ} \mathrm{C}$ ) directly after collection and forced to bring the stigmas to receptivity. At the time the pistillate inflorescences were fully expanded and the ovaries were swollen, we collected one to three entire unpollinated inflorescences per tree from the branches in the greenhouse. We separated the flowers (capsules) from the catkins and dissected 15 to 30 (mean: 16) ovaries from 8 and 9 individual trees of $P$. $\times$ canadensis and $P$. nigra, respectively. The ovary was cut lengthwise with a scalpel and the number of unfertilized ovules per flower was counted using a stereomicroscope. Furthermore, we collected 2 to 23 (mean: 14) fully elongated catkins from the branches to count the number of flowers per catkin. The potential for seed set per catkin was calculated per genet and defined as the mean number of flowers per catkin multiplied by the mean number of ovules per flower. The number of collected catkins and the number of ovaries dissected per genet is given in table 2 . Two-sided t-tests were used to test for significant differences between $P$. nigra and $P$. $\times$ canadensis for: (i) the mean number of ovules per flower, (ii) the mean number of flowers per catkin and (iii) the mean seed set potential per catkin. All these t-tests were performed using S-PLUS ${ }^{\circledR} 6.2$ (Insightful).

\section{RESULTS}

\section{Genotypic diversity of $\boldsymbol{P}$. nigra}

The tri-nucleotide microsatellite locus Wpms22 showed ladders of bands of equal intensity which resulted in scoring difficulties. Including this locus resulted in inconsistency within samples assigned to the same genet for one allele (in a heterozygous state). It is not clear if this is because of technical (PCR-) artefacts, scoring errors or a somatic mutation. We therefore did not include the microsatellite locus Wpms22 to detect samples sharing the same multilocus genotype.

Twenty-six [out of 235 (11\%)] adult trees were identified as hybrids. They were likely $\mathrm{F}_{1}$-hybrids because they were heterozygous at both loci Pmgc14 and Wpms09 showing one allele diagnostic for $P$. deltoides and another specific for $P$. nigra. These 26 trees represented four different hybrid 
Table 4 - Multilocus microsatellite genotypes and number of replicates per genet of Populus nigra along the river IJzer. For each locus, the mean fragment length (in base pairs) of the alleles is given.

\begin{tabular}{cccccccc}
\hline Genet Code & \# Replicates & Pmgc14 & Wpms05 & Wpms09 & Wpms14 & Wpms16 & Wpms19 \\
\hline A & 58 & $205 / 208$ & $282 / 286$ & $250 / 264$ & $253 / 278$ & $149 / 149$ & $215 / 240$ \\
B & 151 & $205 / 208$ & $290 / 294$ & $256 / 264$ & $247 / 265$ & $149 / 149$ & $210 / 245$ \\
\hline
\end{tabular}

genets. After eliminating these hybrid genotypes only 2 different multilocus microsatellite genotypes remained within the 209 black poplar trees sampled. All the black poplar trees sampled were females. The multilocus microsatellite genotypes and the number of replicates per genotype are given in table 4.

\section{Hybridization events with cultivated poplars}

At least one diagnostic allele of $P$. deltoides was detected in $58 \%(64 / 110)$ of the seedlings from the seeds collected on the open pollinated black poplar trees. The probability of correctly identifying hybrid progeny from natural backcrosses of $P$. nigra with $P$. $\times$ canadensis combining the three diagnostic microsatellite markers (assumed to be unlinked) was $87.5 \%$. The number of seedlings showing diagnostic alleles of $P$. deltoides per progeny collected from the open-pollinated $P$. nigra trees is given in table 1 .

P. nigra 'Italica' was identified as a possible father of one seedling (from the tree DI50C).

For every seedling, the attribution of the maternal allele was feasible at each locus; there were no indications for null alleles. As expected, the diagnostic markers Wpms09, Pmgc14 and Wpms18 were heterozygous in the nine reference $\mathrm{F}_{1}$-hybrids and homozygous in the five $P$. deltoides reference clones. Wpms09 showed a $P$. deltoides-specific allele of $234 \mathrm{bp}$, Pmgc14 revealed a $P$. deltoides-specific allele of $193 \mathrm{bp}$ and Wpms 18 of $220 \mathrm{bp}$. For locus Wpms20, Fossati et al. (2003) reported significantly different allele frequencies between $P$. nigra and $P$. deltoides. However, in this study
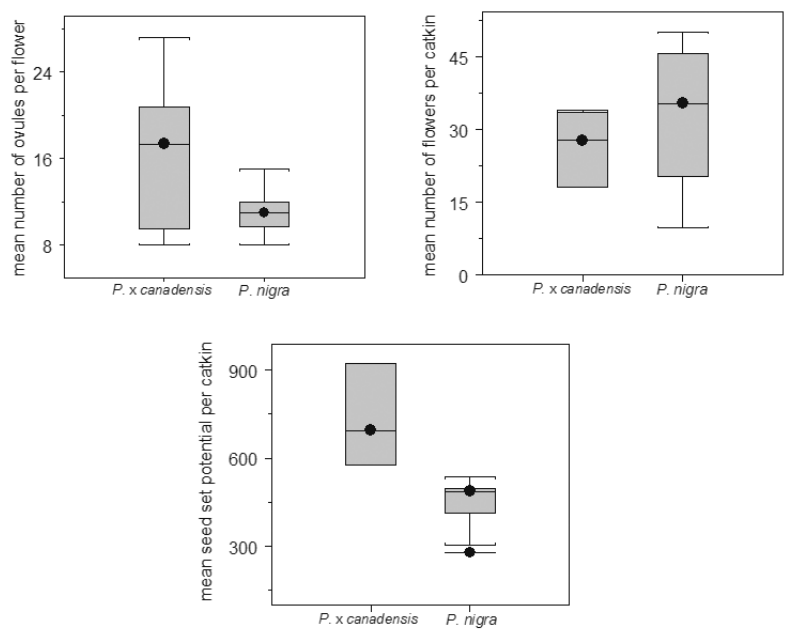

Figure 2 - Box plots of the mean number of ovules per flower, the mean number of flowers per catkin and the mean seed set potential per catkin for Populus $\times$ canadensis and P. nigra, respectively. we did not find the diagnostic alleles for Wpms20 described by Fossati et al. (2003).

\section{Seed set potential}

The potential for seed set per catkin was significantly higher for $P . \times$ canadensis than for $P$. nigra $(\mathrm{t}=3.7818, \mathrm{df}=10, \mathrm{p}$ value $=0.0036)$. The mean maximum potential seeds per catkin was 619 (S.D.: 175) for $P$. $\times$ canadensis and 425 (S.D.: 95) for $P$. nigra (fig. 2). $P . \times$ canadensis produced a significantly higher mean number of ovules per flower (19.9, S.D.: 4.7) compared to $P$. nigra (10.9, S.D.: $2.5 ; \mathrm{t}=19.6074$, $\mathrm{df}=$ 277, p-value =0; fig. 2).

In contrast, $P . \times$ canadensis contained a slightly lower mean number of flowers per catkin (30.9, S.D.: 5.8) compared to P. nigra (38.4, S.D.: $13 ; \mathrm{t}=-3.876, \mathrm{df}=157$, $\mathrm{p}$-value $=0.0002$; fig. 2).

\section{DISCUSSION}

The majority (if not all) of the relict black poplar trees in the valley of the IJzer are female trees. In early spring, conspecific pollen are scarce or even completely absent, except for pollen from the widely planted male cultivar $P$. nigra 'Italica'. Unexpectedly, viable seeds could be collected in the field from all the nine open-pollinated black poplar trees investigated. The majority of the grown seedlings $(58 \%)$ showed at least one allele specific for $P$. deltoides. As clones of $P$. deltoides are not planted in Belgium, alleles of $P$. deltoides in $P$. nigra offspring could only originate from natural hybridization with $P$. $\times$ canadensis males. In addition, it is likely that offspring without species-specific allele of $P$. deltoides at the three diagnostic microsatellite loci also originate from a backcross of $P$. nigra to $P$. $\times$ canadensis, as to our knowledge, no autochthonous $P$. nigra males were present in the vicinity. The expected proportion of hybrid seedlings is therefore likely to be $100 \%$. The probability of correctly identifying hybrid progeny from natural backcrosses of $P$. nigra to $P$. $\times$ canadensis combining the three diagnostic microsatellite markers (assumed to be unlinked) was $87.5 \%$. Combining data from more diagnostic molecular markers, for example additional microsatellites or Single Nucleotide Polymorphisms, would increase the chance of detecting backcross hybridization events (e.g. Meirmans et al. 2010). However, despite the low resolution, the results of this study provide solid evidence for natural hybridization between female $P$. nigra and male $P$. $\times$ canadensis, a process that may affect the evolution of the species-complex (Arnold 1997). It must be noted that, due to the low resolution of our genetic data and to our incomplete knowledge on the geographic location of the numerous cultivated poplar genotypes planted 
in the study area, a paternity analysis aiming to identify the location of individual siring trees was not possible.

Until now, evidence for natural hybridization between female $P$. nigra and male $P$. $\times$ canadensis was rarely found. Only one former study reports on evidence for introgression of genes of $P$. deltoides into the offspring of open pollinated P. nigra (Vanden Broeck et al. 2004). The latter study, also performed in Flanders, concerned only one single case and one single tree seed progeny of $P$. nigra. Also, the results of the latter contrast with other studies in which $P$. $\times$ canadensis growing in the vicinity failed to act as a father to any of the offspring of P. nigra females (Rajora 1986, Heinze 1997, Janssen 1998, Benetka et al. 1999, Fossati et al. 2003, Tabbener \& Cottrell 2003). Despite the rather small sample size, the findings of the present study provide further evidence for natural hybridization of solitary $P$. nigra females with hybrid $P . \times$ canadensis. The rather contrasting results between both studies performed in Flanders and similar other studies performed elsewhere in Europe investigating natural hybridization between female $P$. nigra and male $P$. $\times$ canadensis, may be explained by the local demographic mating environment. It should be noted that the situation of $P$. nigra along the river IJzer in West Flanders with extreme low densities of mainly or exclusively female trees of autochthonous $P$. nigra combined with a high abundance and proximity of $P . \times \mathrm{ca}$ nadensis, is quite exceptional for Europe. The strong limitation of conspecific pollen results in $P$. nigra receiving mainly foreign, heterospecific pollen which may enhance the rate of hybridization. Vanden-Broeck et al. (2012) investigated the potential for hybridization between $P$. $\times$ canadensis and $P$. nigra by a series of pollination experiments in the greenhouse. Using pollen lots of $P$. nigra pollen mixed with pollen of $P$. $\times$ canadensis, $P$. nigra sired a significantly greater number of seeds on its own flowers than $\operatorname{did} P . \times$ canadensis, even when higher proportion of pollen from $P . \times$ canadensis was present in the pollen mix (Vanden-Broeck et al. 2012). This suggests that the risk of hybridization between female $P$. nigra and male $P$. $\times$ canadensis may be reduced when conspecific $P$. nigra pollen are present. In the absence of $P$. nigra pollen, the risk for hybridization with male $P . \times$ canadensis may be higher (Vanden-Broeck et al. 2012).

Only one seedling $(0.9 \%)$ may have been fathered by $P$. nigra 'Italica' as this male cultivar could not be excluded as a potential male parent for one seedling. Former studies report on natural hybridization levels between female autochthonous $P$. nigra with $P$. nigra 'Italica' ( $\mathrm{F}_{1}$-hybrids) of $0 \%$ in the UK (Tabbener \& Cottrel 2003), $1.6 \%$ on the DutchBelgian border (Vanden Broeck et al. 2004) to 2.6\% along the Loire River in France (Chenault et al. 2011). As P. nigra 'Italica' belongs to the species $P$. nigra, flowering synchrony, rather than genetic incompatibility, is likely an important factor in determining natural hybridization. In Belgium P. nigra 'Italica' generally starts flowering before autochthonous P. nigra although an overlap in flowering can occur (Vanden Broeck et al. 2003). Flowering synchrony might be more significant in Southern regions, which, at least partly, may explain the higher levels of hybridization observed in France along the Loire River by Chenault et al. (2011).

The extremely low genotypic diversity of $P$. nigra in the IJzer valley may increase the potential risk of genetic assimi- lation through hybridization by the more numerous cultivated $P . \times$ canadensis. The fact that hybridization frequencies can be highly variable between populations and strongly depend on the local mating environment was also discussed by Field et al. (2011) in a study of mating patterns between eucalyptus species. Only two different multilocus genotypes or genets, both replicated dozens of times, were detected within the samples of $P$. nigra collected in the IJzer river valley. A study of the genetic diversity in nine gene bank collections of $P$. nigra, including the Belgian P. nigra gene bank, indicated that the combined data of five specific microsatellite loci (Pmgc14, Wpms09, Wpms14, Wpms16 and Wpms20), of which four are used in this study, revealed sufficient statistical power for the identification of duplicates of the same genet (Storme et al. 2004). Because we used even more microsatellite loci, we are confident that the microsatellite data used in this study were sufficient to reliably assign samples with the same genotype to the same genet.

The high number of genetic replicates is probably due to the human influence on the species. Nowadays, black poplars growing in the valley of the IJzer River generally grow in the neighbourhood of farms. It is very likely that, several decades ago, autochthonous poplar trees growing near the river have been propagated by farmers and planted near their farms as multipurpose trees (for fuel wood, fodder, timber, shading or as a windbreak). Poplars can be easily propagated through striking of cuttings. The collection of plant material from a few trees may have led unconsciously to multiple replicates of a few genets. Additionally, these might have been propagated and exchanged between neighbouring farmers resulting in the high number of duplicates of only two genets of $P$. nigra in the valley of the IJzer. A similar situation was reported for P. nigra in the region of the Usk River, on the border between England and Wales (UK) (Cottrell et al. 2002, Smulders et al. 2008b). Only two different genets were identified within 72 black poplar trees sampled (all of them males) along the Usk based on seven microsatellite markers. Likewise, the area around Aylesbury (northwest of London), which has a large number of black poplars, contains a very low number of genets (Cottrell et al. 2002). A high number of ramets from a single genet where also found along the Rhine in the Netherlands (Smulders et al. 2008b). In contrary, no duplicates of genets were found in samples collected from black poplar populations along more dynamic southern and eastern European river systems like the French river Drôme, the Spanish river Ebro, the Czech part of the river Labe and in Ukraine along the rivers Tysa and Prut (Smulders et al. 2008b). The results of this study support the findings of Smulders et al. (2008b) indicating that the genetic diversity of black poplar is related with the river system dynamics. In Flanders, the UK and some regions of the Netherlands, natural patterns of river flow and water table levels are altered. This limits the opportunities for sexual reproduction and explains the current lack of natural populations of black poplar in Belgium and in the UK (Cottrell et al. 2002). In these countries, man unconsciously prevented the extinction of black poplar by vegetative propagation. However, this has resulted in an extreme low genetic diversity, limiting the evolutionary potential of the species and increasing the susceptibility to diseases. 
In addition to the 'pollination threat' discussed above, $P$. $\times$ canadensis may also outcompete $P$. nigra in terms of numbers of seeds produced. To our knowledge, this is the first study comparing the potential for seed set of $P$. $\times$ canadensis and $P$. nigra. Despite the small sample size, our results suggest that the potential for seed set per catkin is higher for $P$. $\times$ canadensis compared to $P$. nigra. In addition, the number of ovules per ovary was significantly higher for $P$. $\times$ canadensis compared to $P$. nigra. This indicates that the cultivated $P$. $\times$ canadensis may have a higher reproductive seed set potential per catkin compared to the native P. nigra. However, there are numerous other factors that influence reproductive potential like the number of catkins per tree, pollen production, pollen availability, pollen viability, pollen interaction, seed production and seed viability. Vanden-Broeck et al. (2012) investigated the impact of pre-zygotic mating barriers like pollen viability and heterospecific mixed pollen loads on the reproductive potential of $P . \times$ canadensis and $P$. nigra. They found that, in greenhouse experiments sterility of $P . \times \mathrm{Ca}$ nadensis can be overcome by the interaction with untreated pollen of the related $P$. nigra. Insight in the different aspects determining the reproduction potential of the cultivated poplars will help to explain the observations of this and former field studies.

There is currently some interest in Flanders in the restoration of river dynamics and floodplain ecosystems due to several recent floods that have caused high damage in densely populated regions. Riparian forests with $P$. nigra as a key species can help in flood control, for example by stabilizing stream banks and by reducing erosion. It is clear from this study that in the valley of the IJzer, hybridization between native and cultivated poplars occurs and that there is a lack of adult genetic resources to establish new populations of P. nigra on sites where river dynamics are restored. To reduce the risks for introgression and genetic swamping of $P$. nigra by $P . \times$ canadensis, we strongly advise reforestation with plant material including other genotypes of $P$. nigra from neighbouring regions taking into account balanced sex-ratios. Plant material for reforestation may originate for example from the Netherlands or from populations along the French rivers Oise and Seine. Forest reproductive material of known provenance is available on the market in the Netherlands and will soon be on the market from the French rivers Oise and Seine. Enlarging the genetic diversity will promote the survival of the population on the long term and will likely limit the potential for introgression of cultivated genes into the offspring of $P$. nigra along the IJzer river. Regular genetic monitoring is strongly advised to enable the evaluation of restoration actions and provide good opportunities to track hybridization events over time (Schwartz et al. 2007).

\section{ACKNOWLEDGEMENTS}

We thank Wim Declercq, André Meersman, Serge Goossens and Paul Remy for collecting the seeds and for their superb assistance in the greenhouse. We also thank An Van Bruesegem, Leen Verschaeve, David Halfmaerten, Nancy Van Liefferinge and Sabrina Neyrinck for the excellent laboratory assistance.

\section{REFERENCES}

Arnold M.L. (1997) Natural hybridization and evolution. New York , Oxford University Press.

Benetka V., Mottl J., Vacková K., Pospísková M., Dubský M. (1999) Estimation of the introgression level in Populus nigra L. populations by means of isozyme gene markers. Silvae Genetica 48: 218-223.

Burd M., Ashman T.L., Campbell D.R., Dudash M.R., Johnston M.O., Knight T.M., Mazer S.J., Mitchell R.J., Steets J.A., Vamosi J.C. (2009) Ovule number per flower in a world of unpredictable pollination. American Journal of Botany 96: 115-1167. http://dx.doi.org/10.3732/ajb.0800183

Cervera M.-T., Storme V., Ivens B., Gusmao J., Liu Ben H., Hostyn V., Van Slycken J., Van Montagu M., Boerjan W. (2001) Dense genetic linkage maps of three Populus Species (Populus deltoides, P. nigra and P. trichocarpa) based on AFLP and microsatellite markers. Genetics 158: 787-809.

Chenault N., Arnaud-Haond S., Juteau M., Valade R., Almeida J.L., Villar M., Bastien C., Dowkiw A. (2011) SSR-based analysis of clonality, spatial genetic structure, and introgression from the Lombardy poplar into a natural population of Populus nigra L. along the Loire River. Tree Genetics \& Genomes 7(6):1-14. http://dx.doi.org/10.1007/s11295-011-0410-6

Cottrell J.E., Tabbener H.E., Forrest G.I. (2002) Distribution of variation in British black poplar: the role of human management. In: van Dam B., Bordács S. (eds) Genetic diversity in river populations of European Black poplar: 77-84. Budapest, Csiszar Nyomda Ltd.

Csencsics D., Angelone S., Paniga M., Rotach P., Rudow A., Sabiote E., Schwab P., Wohlhauser P., Holderegger R. (2009) A large scale survey of Populus nigra presence and genetic introgression from non-native poplars in Switzerland based on molecular identification. Journal for Nature Conservation 17: 142-149. http://dx.doi.org/10.1016/j.jnc.2009.01.004

Ellstrand N. (2003) Current knowledge of gene flow in plants: implication for transgene flow. Philosophical Transactions of the Royal Society Biological Sciences 358: 1163-1170. http:/ dx.doi.org/10.1098/rstb.2003.1299

Field D.L., Ayre D.J., Whelan R.J., Young A.G. (2011) The importance of pre-mating barriers and the local demographic context for contemporary mating patterns in hybrid zones of Eucalyptus aggregata and Eucalyptus rubida. Molecular Ecology 20: 23672379. http://dx.doi.org/10.1111/j. 1365-294X.2011.05054.X

Fossati T., Grassi F., Sala F., Castiglione S. (2003) Molecular analysis of natural populations of Populus nigra L. intermingled with cultivated hybrids. Molecular Ecology 12: 2033-2043. http:// dx.doi.org/10.1046/j.1365-294X.2003.01885.x

Heinze B. (1997) A PCR Marker for a Populus deltoides allele and its use in studying introgression with native European Populus nigra. Belgian Journal of Botany 129: 123-130.

Heinze B. (2008) Genetic traces of cultivated hybrid poplars in the offspring of native Populus nigra in Austria. Preslia 80: 365374.

Janssen A. (1998) Artbestimmung von Schwarzpappeln (Populus nigra L.) mit Hilfe von Isoenzymmustern und Uberprüfung der Methode an Altbäumen, Absaaten von kontrollierten Kreuzungen und freien Abblüten sowie Naturverjüngungen. In: Weisgerber H., Janssen A. (eds) Band 24 Die Schwarzpappel: 32-42. Hann. Münden, Hessischen Landesanstalt für Forsteinrichtung.

Lefèvre F., Kajba D., Heinze B., Rotach P., de Vries S.M.G., Turok J. (2001) Black poplar: a model for gene resource conservation in forest ecosystems. The Forest Chronicle 77: 239-244. http:// dx.doi.org/10.5558/tfc 77239-2 
Meirmans P.G., Lamothe M., Gros-Louis M.C., Khasa D., Perinet P., Bousquet J., Isabel N. (2010) Complex patterns of hybridization between exotic and native North American poplar species. American Journal of Botany 97: 1688-1697. http://dx.doi. org/10.3732/ajb.0900271

Peakall R., Smouse P.E. (2006) GENALEX 6: genetic analysis in Excel. Population genetic software for teaching and research. Molecular Ecology Notes 6: 288-295. http://dx.doi. org/10.111/j.1471-8286.2005.01155.x

Pinon K. (1992) Variability in the genus Populus in sensitivity to Melampsora rusts. Silvae Genetica 41: 25-34.

Pospíšková M., Šálková I. (2006) Population structure and parentage analysis of black poplar along the Morava River. Canadian Journal of Forest Research 36: 1067-1076. http://dx.doi. org/10.1139/x06-003

Rajora O.P. (1986) Mating systems and fertilizing pollen gene pools of Populus deltoides Marsh. and P. nigra L. clones located in different compatible species neighbourhoods as inferred from isozyme analysis. In: Proceedings of the $20^{\text {th }}$ Canadian Tree Improvement Association, part 2: 134-141. Ottawa, Canadian Forest Service.

Smulders M.J.M., van der Schoot J., Arens P., Vosman B. (2001) Trinucleotide repeat microsatellite markers for Black poplar (Populus nigra L.). Molecular Ecology Notes 1: 188-190. http://dx.doi.org/10.1046/j.1471-8278.2001.00071.X

Smulders M.J.M., Beringen R., Volosyanchuk R., Vanden Broeck A., van der Schoot J., Arens P., Vosman B. (2008a) Natural hybridisation between Populus nigra L. and P. $\times$ canadensis Moench. Hybrid offspring competes for niches along the Rhine river in the Netherlands. Tree Genetics \& Genomes 4: 663-675. http://dx.doi.org/10.1007/s11295-008-0141-5

Smulders M.J.M., Cottrell J.E., Lefèvre F., van der Schoot J., Arens P., Vosman B., Tabbener H.E., Grassi F., Fossati T., Castiglione S., Krystufek V., Fluch S., Burg K., Vornam B., Pohl A., Gebhardt K., Alba N., Agúndez D., Maestro C., Notivol E., Volosyanchuk R., Pospísková M., Bordács S., Bovenschen J., van Dam B.C., Koelewijn H.P., Halfmaerten D., Ivens B., Van Slycken J., Vanden Broeck A., Storme V., Boerjan W. (2008b) Structure of the genetic diversity in black poplar (Populus nigra L.) populations across European river systems: Consequences for conservation and restoration. Forest Ecology and Management 255: 1388-1399. http://dx.doi.org/10.1016/j. foreco.2007.10.063

Stettler R.F., Zsuffa L., Wu R. (1996) The role of hybridization in the genetic manipulation of Populus. In : Stettler R.F., Bradshaw H.D., Heilman P.E. Jr., Hinckley T.M.(eds) Biology of Populus and its implications for management and conservation: 87-112. Ottawa, NRC Research Press.

Storme V., Vanden Broeck A., Ivens B., Halfmaerten D., Van Slycken J., Castiglione, S., Grassi F., Fossati T., Cottrell J.E., Tabbener H.E., Lefèvre F., Saintagne C., Fluch S., Krystufek V., Burg K., Bordács S., Gebhardt K., Vornam B., Pohl A., Alba N., Agúndez D., Bovenschen J., van Dam B.C., van der Schoot J., Vosman B., Boerjan W., Smulders M.J.M. (2004) Ex-situ con- servation of Black poplar in Europe: genetic diversity in nine gene bank collections and their value for nature development. Theoretical and Applied Genetics 108: 969-981. http://dx.doi. org/10.1007/s00122-003-1523-6

Strauss S.H., Difazio, S.P., Meilan R. (2001) Genetically modified poplars in context. Forestry Chronicle 77: 271-279.

Schwartz M.K., Luikart G., Waples R.S. (2007) Genetic monitoring as a promising tool for conservation and management. Trends in Ecology and Evolution 2: 25-33. http://dx.doi.org/10.1016/j. tree.2006.08.009

Tabbener H.E., Cottrell J.E. (2003) The use of PCR based DNA markers to study the paternity of poplar seedlings. Forest Ecology and Management 179: 363-376. http://dx.doi.org/10.1016 S0378-1127(02)00538-8

van der Schoot J., Pospísková M., Vosman B. (2000) Development and characterization of microsatellite markers in black poplar (Populus nigra L.). Theoretical and Applied Genetics 101: 317322. http://dx.do1.org/10.1007/s001220051485

Vanden Broeck A., Cox, K., Quataert, P., Van Bockstaele, E., Van Slycken, J. (2003a) Flowering phenology of Populus nigra L., P. nigra cv. italica and P. $\times$ canadensis Moench. and the potential for natural hybridisation in Belgium. Silvae Genetica 52: 280-283.

Vanden Broeck A., Storme V., Cottrell J. E., Boerjan W., Van Bockstaele E., Quataert P., Van Slycken, J. (2004) Gene flow between cultivated poplars and native black poplar (Populus nigra L.): A case study along the river Meuse on the Dutch-Belgian border. Forest Ecology and Management 197: 307-310. http:// dx.doi.org/10.1016/j.foreco.2004.05.021

Vanden Broeck A., Cottrell J., Quataert P., Breyne P.,Storme V., Boerjan W., Van Slycken J. (2006) Paternity analysis of Populus nigra $\mathrm{L}$. offspring in a Belgian plantation of native and exotic poplars. Annals of Forest Science 63: 783-790. http://dx.doi. org/10.1051/forest:2006060

Vanden-Broeck A., Cox K., Michiels B., Verschelde P., Villar M. (2012, Online First ${ }^{\mathrm{TM}}$ ) With a little help from my friends: hybrid fertility of exotic Populus $\times$ canadensis enhanced by related native Populus nigra. Biological Invasions. http://dx.doi. org/10.1007/s10530-012-0180-6

Vander Mijnsbrugge K., Cox K., Van Slycken J. (2005) Conservation approaches for autochtonous woody plants in Flanders. Silvae Genetica 54: 197-202.

Ziegenhagen B., Gneuss S., Rathmacher G., Leyer I., Bialozyt R., Heinze B., Liepelt S. (2008) A fast and simple genetic survey reveals the spread of poplar hybrids at a natural Elbe river site. Conservation Genetics 9: 373-379. http://dx.doi.org/10.1007/ s10592-007-9349-4

Manuscript received 26 May 2011; accepted in revised version 13 Mar. 2012.

Communicating Editor: Myriam Heuertz. 